\title{
Gut microbiome, Vitamin D, ACE2 interactions are critical factors in immune-senescence and inflammaging: key for vaccine response and severity of COVID-19 infection
}

\author{
Santosh Shenoy ${ }^{1}$ (D)
}

Received: 9 April 2021 / Revised: 21 September 2021 / Accepted: 23 September 2021 / Published online: 5 November 2021

(c) The Author(s), under exclusive licence to Springer Nature Switzerland AG 2021

\begin{abstract}
Background The SARS-CoV-2 pandemic continues to spread sporadically in the Unites States and worldwide. The severity and mortality excessively affected the frail elderly with co-existing medical diseases. There is growing evidence that crosstalk between the gut microbiome, Vitamin D and RAS/ACE2 system is essential for a balanced functioning of the elderly immune system and in regulating inflammation. In this review, we hypothesize that the state of gut microbiome, prior to infection determines the outcome associated with COVID-19 sepsis and may also be a critical factor in success to vaccination. Methods Articles from PubMed/Medline searches were reviewed using a combination of terms "SARS-CoV-2, COVID-19, Inflammaging, Immune-senescence, Gut microbiome, Vitamin D, RAS/ACE2, Vaccination".

Conclusion Evidence indicates a complex association between gut microbiota, ACE-2 expression and Vitamin D in COVID19 severity. Status of gut microbiome is highly predictive of the blood molecular signatures and inflammatory markers and host responses to infection. Vitamin D has immunomodulatory function in innate and adaptive immune responses to viral infection. Anti-inflammatory functions of Vit $\mathrm{D}$ include regulation of gut microbiome and maintaining microbial diversity. It promotes growth of gut-friendly commensal strains of Bifida and Fermicutus species. In addition, Vitamin D is a negative regulator for expression of renin and interacts with the RAS/ ACE/ACE-2 signaling axis. Collectively, this triad may be the critical, link in determination of outcomes in SARS-CoV-2 infection. The presented data are empirical and informative. Further research using advanced systems biology techniques and artificial intelligence-assisted integration could assist with correlation of the gut microbiome with sepsis and vaccine responses. Modulating these factors may impact in guiding the success of vaccines and clinical outcomes in COVID-19 infections.
\end{abstract}

Keywords COVID-19 sepsis · Gut microbiome $\cdot$ Vitamin D $\cdot$ ACE2 $\cdot$ Immune-senescence $\cdot$ Inflammaging $\cdot$ Vaccination

\section{Introduction}

The SARS-CoV-2 pandemic continues to spread sporadically in the Unites States and worldwide. We are one year into the pandemic and there is no clear therapy, and the global vaccination of the population is in its early stages and too soon to determine any long-term efficacy in the vaccinated population. To complicate matters further, there is

Responsible Editor: John Di Battista.

Santosh Shenoy

shenoy2009@ hotmail.com

1 Department of Surgery, Kansas City VA Medical Center, University of Missouri Kansas City, 4801 E Linwood Blvd., Kansas City, MO 64128, USA appearance of breakthrough infections with mutant strains of SARS-CoV-2 globally, with high infectiousness and varying severity $[1,2]$. This current COVID-19 pandemic has established that our understanding of the pathophysiology of sepsis remains incomplete and further research is needed to fill these gaps. It has been demonstrated that combinations of risk factors, such as medical comorbidities, older age group, mitochondrial dysfunction, along with high nasopharyngeal viral load, are predictors for worse outcomes [3, 4].

There is a wide heterogeneity in COVID-19 disease severity, ranging from asymptomatic to fatal disease. However, it is well established that elderly patients are susceptible to severe sepsis and death compared with younger population. Even among the elderly, it is the frail patients with co-existing illnesses, signifying advanced biological age rather than chronological age which influences this susceptibility [5]. 
Immune-senescence and inflammaging are natural phenomenon associated with aging. It defines frailty and biological susceptibility to COVID-19 sepsis and its outcomes. Immune senescence is described as age-related remodeling of immune cell repertoire and functions in the human physiology. Inflammaging represents a state of chronic inflammation, elevated cytokine levels, associated with inflammasome activation and aging [6]. Both immune-senescence and inflammaging are complex interrelated systemic processes and encompass both circulating cells and tissue immune system, such as mucosal lining of respiratory and gastrointestinal (GI) tract, resulting in changes, for example in the microbiome. The GI tract has a long surface area and in addition to its absorptive, metabolic functions also harbors a robust immune system and function [7]. There is growing evidence that cross-talk between gut microbiome and immune system is vital for priming, development, and function of immune cells, both locally and systemically. This can affect the overall health of an organism [8]. Gut immune system is associated with severity of lung infections, pneumonia and sepsis through gut lung axis [9, 10]. Dysbiosis is defined as an alteration in the composition of gut microbiome or the production of abnormal microbial peptides that may disrupt the natural symbiotic harmony between the host and microbiome with deleterious consequences. Dysbiosis along with immune-senescence and inflammaging leads to progressive reduction in the ability to trigger effective antibody and cellular responses against infections and vaccinations. This is demonstrated in seasonal respiratory tract viruses, such as influenza infections and vaccinations $[6,11,12]$.

There appears to be a complex interaction between gut microbiota, ACE-2 expression and Vitamin D in COVID19 pathogenesis. This triad may provide the critical, missing link in determination of outcomes in SARS-CoV-2 infection (Fig. 1). We hypothesize that the state of gut microbiome, prior to infection determines the outcome associated with COVID-19 sepsis. In this review, we present several lines of evidence and discuss how inflammaging, immune-senescence and immune health of gut may affect the severity of COVID-19 sepsis and responses to vaccination. Simple, but strategic nutritional, nonpharmacologic interventions may immune-modulate the elderly immune system and mitigate risks and severity of COVID-19 infections. An in-depth understanding of these mechanisms will have an impact in guiding the success of vaccines and discovery of novel diagnostic and therapeutic targets which are needed against novel SARS-CoV-2 virus.

\section{Immune-senescence and inflammaging in COVID pathogenesis}

Immune-senescence and inflammaging encompass both innate and adaptive immunity. There are changes in composition of cell types, alterations in gene expression, proteins and signaling pathways $[12,13]$. This leads to a decline in immune efficacy, with increased vulnerability to infectious diseases, and age-related inflammatory diseases. It also diminishes responses to vaccinations in the elderly [6, 11-14]. We first begin our discussion with the fundamental features associated with immune-senescence and inflammaging.

Anatomic and physiologic changes with aging, such as involution of thymus, bone marrow suppression and lymph node fibrosis, contribute to immune-senescence [11-13, 15, 16]. There are several hallmarks of immunesenescence. Compositions of innate and adaptive immune cells, such as neutrophils, monocytes and macrophage, natural killer (NK) cell, dendritic (DC) cells, B and T lymphocytes, are altered and decline in their functions. Neutrophils have diminished ability for bacterial phagocytosis and oxidative burst. Macrophages show reduced chemotaxis, migration and phagocytosis, and decreased cytokine production [17]. In contrast, inflammaging may be associated with chronic infiltration of tissue and organs by immune cells but with dysregulated function. For example, inflammaging is accompanied by a significant increase in NK cells, but with functional deficits $[12,17]$.

\section{Impact on innate immunity}

There are consequences of immune-senescence in COVID19 sepsis. Changes in composition of functional DC cells, dysfunctional NK cell cytotoxicity and loss of naïve T cells are critical in COVID-19 infections. There is a delay in type I interferon (IFN) activation and together with dysfunctional NK cell-mediated cytotoxicity impedes viral clearance. Early type I IFNs is crucial for restricting viral replication and dissemination, through autocrine and paracrine type I IFN receptor (IFNAR) signaling [11-13, 18, 19].

DC cells are antigen-presenting cells (APCs). They express toll-like receptors (TLRs) that recognize conserved pathogen-associated molecular patterns (PAMPs) on microbes and are key regulators in antimicrobial host defense. Recognition of antiviral components by TLRs is vital to the secretion of type I IFN and cytokines that facilitate the coordination of innate antiviral immunity [11, 12, 18] Subsequently DCs present these peptides through MHC II (major histocompatibility) program to T and B lymphocytes, thus stimulating adaptive and humoral immune responses, respectively. The functions of DCs are impaired in elderly with delayed maturation and migration demonstrated during microbial invasion [13]. Experiments have demonstrated that DCs from lymph nodes in adult mice have diminished ability to prime $\mathrm{T}$ cells compared to DCs from young mice. This impaired function is due to 

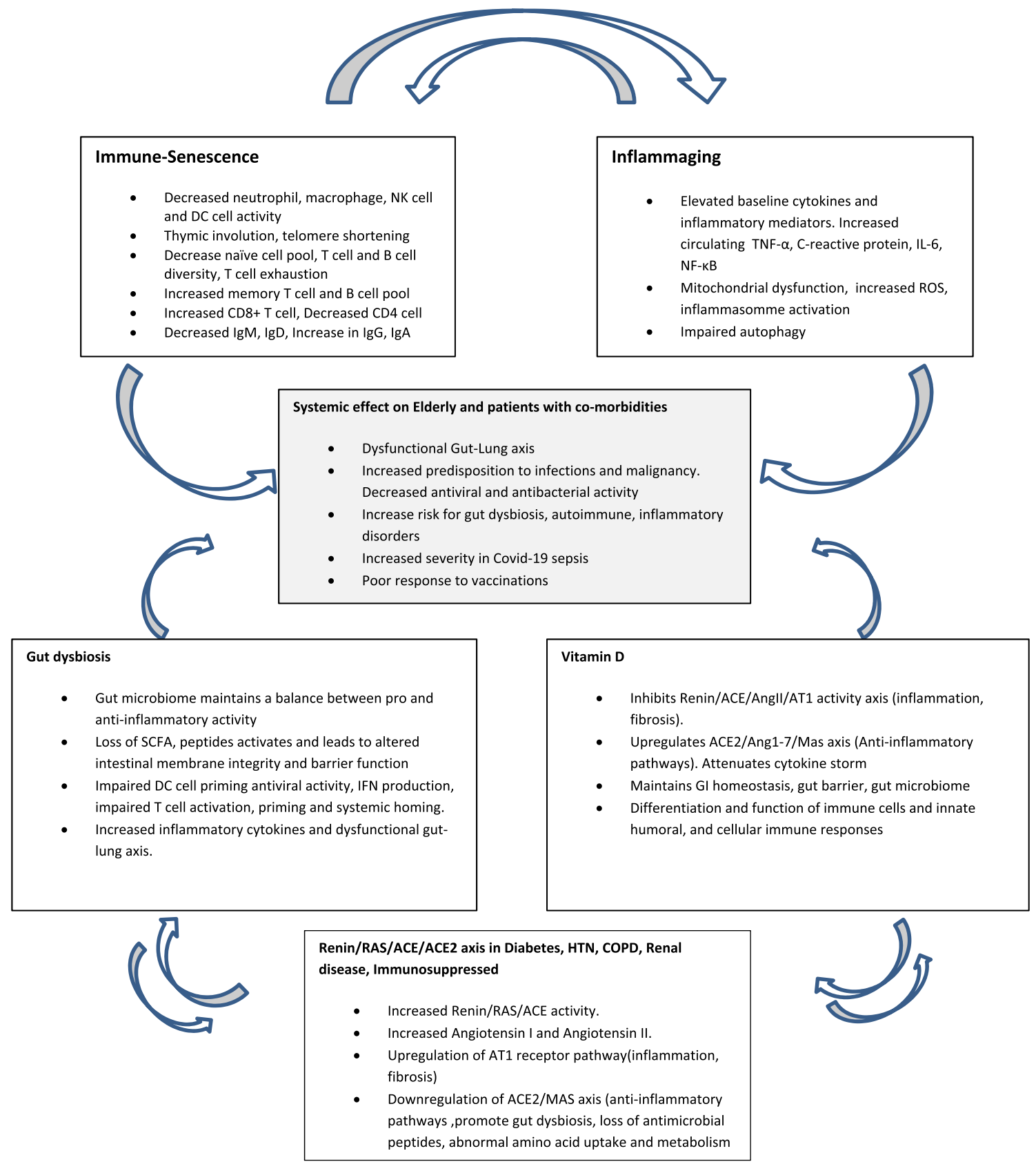

Fig. 1 The interplay between immune-senescence and inflammaging along with gut microbiome disruption, Vit D deficiency and altered RAS/ACE2 axis (critical triad). Although the phenomenon of immune-senescence and inflammaging cannot be completely avoided due to natural physiological aging processes, the critical triad may modulate the severity especially in the elderly. Gut microbial dysbiosis causes disruption of innate antiviral immunity and protective

decreased expression of co-stimulatory proteins necessary for $\mathrm{T}$ cell recognition and activation and decrease in IL-12 production by DCs [20].

SARS-CoV-2 virus has established diverse strategies for survival by interfering with innate immunity particularly DCs functions and interferon production. Possible gut-lung axis. Vit D deficiency, through the loss of anti-renin activity and protective ACE2/Ang1-7/MAS anti-inflammatory activity causes hyper-inflammatory state. Vit D deficiency together with decreased ACE2 signaling pathways also disrupt protective gut barrier activity and together with disruption of gut microbiome further exacerbate the immune system thus causing a vicious cycle of hyper-inflammation i.e.; the cardinal feature in COVID-19 sepsis

mechanisms include avoiding recognition by pattern recognition receptors (PRRs), compromising cytoplasmic retinoic acid inducible gene (RIG-I) or TLR signaling and inhibiting interferon regulatory factor (IRF3) activation [4, 21, 22] SARS-CoV-2 could also antagonize the signaling pathway downstream of IFN production by blocking the nuclear 
translocation of JAK/STAT1 pathways [23]. Degradation of intracellular IFN and delay of early antiviral defense IFN response, juxtaposed with elevated cytokine, and subsequent exaggerated $\mathrm{T}$ cell response define the hyper-inflammation features of COVID-19 [13, 19, 24, 25].

This hyper-inflammatory response was demonstrated in critically ill patients with COVID-19 where-in an impaired early interferon (IFN) type I response is characterized by lack of IFN- $\beta$, IFN- $\alpha$ production and activity. These patients exhibited persistent viremia and an exacerbated inflammatory response $[25,26]$. Lei et al. demonstrated that SARSCoV-2 viral proteins: NSP1, NSP3, NSP12, NSP13, NSP14, ORF3, ORF6 and M protein inhibit IFN- $\beta$ promoter activation and act as intracytoplasmic IFN antagonist. This delay in intracellular antiviral response enables the virus to replicate rapidly. Large amounts of viral transcripts with high viral loads were observed before the IFN induction in SARS-CoV-2-infected cells [22]. Therefore, lack of timely and robust early antiviral response is central in COVID-19 pathogenesis [22, 25, 26].

\section{Impact on the adaptive immunity}

Similar to its effects on innate immunity, immune-senescence and inflammaging also impact the adaptive immune system. The thymus begins to involute with onset of puberty and there is significant shift in $\mathrm{T}$ cell immune profile with aging. There is a relative paucity of naïve $T$ cells with abundance in differentiated memory $\mathrm{T}$ and $\mathrm{B}$ cells. This predisposes elderly to a blunted antibody and antiviral response, especially to novel pathogens and antigens. The decrease in naïve cells seems related to changes in sex hormones and to decrease of IL-7, a hematopoietic growth factor secreted by stromal cells in bone marrow and thymus [12].

Decrease in $\mathrm{T}$ cell diversity with fewer naïve $\mathrm{T}$ cells, reversal of $\mathrm{CD} 4+/ \mathrm{CD} 8+$ cell ratio and increase in differentiated memory $\mathrm{T}$ cell population signify immune senescence. Further chronic metabolic diseases, chronic viral infections shift the immune system toward an inflammatory, autoimmune, profile $[12,13,20]$.

CD4+ T cell profile demonstrates significant changes with aging. The CD4+ profile consists of Th1, Th2, Th17 and Treg (Regulatory T cells). Th1/CD4+ cells are proinflammatory and secrete IFN- $\gamma$, IL-1, and IL-2. Th2/ CD4+ cells are anti-inflammatory and secrete IL-4, IL-10 that tempers down the Th1 response to prevent uncontrolled damage due to cytokine storm. In a normal physiological state, the Th1/Th2 ratio is low and Th2 anti-inflammatory cells are upregulated. This is observed in healthy elderly patients $[13,17]$. However, in the presence of an infection, a smooth transition to upregulate Th1 profile is necessary, to eliminate invading viruses and other pathogens but minimize tissue destruction [17]. Dysregulated function in this switch in the elderly leads to the classical cytokine storm observed in the COVID-19 sepsis [13, 27]. SARS-CoV-2 infection has demonstrated lymphopenia associated with severe sepsis. In most COVID-19 patients, there is a decrease in $\mathrm{CD} 4^{+}$and $\mathrm{CD}^{+} \mathrm{T}$ cell counts and in $\mathrm{CD} 4^{+} / \mathrm{CD}^{+}$ratio. In addition, $\mathrm{T}$ cells have demonstrated signs of exhaustion [27].

Experiments on mice have demonstrated the interaction of respiratory viral infections, such as influenza virus with gut microbial and immune system through gut lung axis. Lung-derived CD4+ T cell destroys microbiota homeostasis and promotes resident Th17 cell polarization. Gut epithelium produces chemokines CCL25/CCR9 that mediates the recruitment of lung-derived $\mathrm{CD} 4+\mathrm{T}$ cell into the small intestine. CCL25-CCR9 axis contributes to altering the composition of the intestinal microbiota after influenza infection and development of intestinal inflammation by recruiting these effector lymphocytes into the intestinal mucosa [28]. Elderly are particularly susceptible to these effects as there is upregulated pro-inflammatory Th17 cells with loss of anti-inflammatory TREG activity associated with immune senescence [13].

Age-related immune senescence also affects B cell repertoire. There is reduced diversity and number of B cells and receptors as well as immunoglobulin isotypes and a decrease in specific humoral immune responses against new extracellular pathogens. There is a shift from immunoglobulin produced by naïve cells (IgD, $\operatorname{IgM})$ to immunoglobulin produced by memory B cells (IgG, IgA) [12]. Impaired functions of DC together with loss of naïve T cells are primary factors for suboptimal immune response to viral infections in elderly [12, 29].

Other important contributor to immune senescence includes loss of telomerase activity with telomere shortening in aged T cells $[12,17,30]$. T cells upregulate telomerase activity to compensate for telomere loss, incurred during proliferation in response infections and chronic inflammatory conditions. However, repeated antigen exposure as seen with chronic antigenic stimulation by Herpes and CMV viruses leads to clonal expansion of memory $\mathrm{T}$ cell phenotype. This results in telomere shortening leading to replicative senescence. These senescent, exhausted $\mathrm{T}$ cells do not express the co-stimulatory molecule $\mathrm{CD} 28$, required for activation of $\mathrm{T}$ cells and also express immune check point inhibitors such as PD-1 and the cytotoxic T-lymphocyte antigen (CTLA)-4 [12, 13, 15, 17, 30-32]. T cell exhaustion and anergy and its positive correlation with severity of sepsis are demonstrated in SARS-CoV-2 infections. T cells from COVID-19 patients have significantly higher levels of exhausted marker, such as PD-1 and Tim-3 expression [27, 33]

Chronic medical conditions associated with aging, such as diabetes, hyperlipidemia, and chronic inflammatory diseases lead to inflammaging. Chronic chemical, physical, 
and nutritional antigenic stimulation also trigger oxidative stress and inflammation. Inflammaging represents a state of chronically elevated cytokine levels and associated inflammasome activation. The markers for inflammaging include TNF- $\alpha$, C-reactive protein, IL- 6, NF- $\mathrm{\kappa B}$ and are chronically elevated in the elderly [34]. Mitochondrial dysfunction with increased reactive oxygen species (ROS), inefficient oxidative-phosphorylation and loss of mitochondrial antiviral signaling (MAVS) are associated with aging and may contribute to immune-senescence and inflammaging $[4,17$, $35,36]$. Impaired autophagy of damaged cells, elevated reactive oxygen species (ROS) and elevated levels of cellular dysfunctional proteins result in further activation of TLRs and inflammasomes and thus a chronic inflammatory state $[13,17,20]$.

Collectively, this evidence suggests that aging-associated immune-senescence and inflammaging contributes to a diminished and altered response by the innate and adaptive immunities to acute viral infections such as novel SARSCoV-2 infections [12, 13, 15, 18, 30-32].

\section{Gut immune system}

The GI tract has an elaborate, dynamic, complex immune system called gut-associated lymphoid tissue (GALT). It is interspersed with lymphatic tissues called Peyer's patches and extensive sub-epithelial immune cell repertoire and mesenteric lymph nodes [37]. This complex immune environment is constantly exposed to challenges arising, both in the lumen and systemic internal environment [7]. There is normal physiological mucosal turn over and shedding, intermittent luminal trauma from ingested food, loss of integrity of cell junctions which releases additional antigens. The immune cells constantly sample food antigens, pathobiont, such as other non-commensal bacteria, viruses and other foreign peptides $[37,38]$. The gut epithelium along with the immune cells produces protective factors, such as secretory $\operatorname{IgA}, \alpha$-Defensins, antimicrobial peptides and mucus. Immune cells in gut remain vigilant through complex interactions and partake in a delicate balance between homeostasis, tolerance and inflammation. Tipping this balance may lead to increased risk for sepsis (translocation, growth of pathobiont) or excessive immune destruction (autoimmunity) $[7,8,39]$.

Systemic immune-senescence and inflammaging also have damaging effects on the GI tract and dysfunctional gut immune system is associated with severity of lung infections, pneumonia and sepsis through gut lung axis $[9,15$, 28]. The state of gut function and its physiological health, such as dysbiosis, vitamin D deficiency, poor nutrition, obesity, along with COVID-19-related factors, such as viral load, may determine the outcome associated with COVID19 sepsis $[3,12,18]$.

GI tract also expresses ACE-2 receptors, and it is confirmed that SARS-CoV-2 virus commonly infects the GI tract epithelium. The duration of viral replication varies greatly, and prolonged shedding of viral RNA in stool samples has been reported after resolution of symptoms [40-42]. In the subsequent sections, we discuss the interaction between dysbiosis, ACE-2 expression and Vitamin D with the gut immune system, and its possible association with severity in COVID-19 sepsis.

\section{Complex interaction between microbiota, ACE-2 expression and Vitamin D in COVID pathogenesis: the missing link: (Fig. 1)}

Healthy microbiome is essential in development and balancing the function of both pro- and anti-inflammatory T-cell pathways [8, 43, 44]. Baseline dysbiosis is demonstrated to have a major impact on the local and systemic immunity by altering the gastrointestinal tract environment [45]. Aging is associated with frailty, malnutrition, generalized atherosclerosis resulting in decreased mucosal blood flow and villous atrophy. Intestinal dysbiosis shifts the intestinal microbiota from obligate anaerobes, such as Bifidobacterium spp., Lactobacillus spp., and Faecalibacterium prausnitzii to facultative anaerobes, such as pathogenic Streptococci, Staphylococci, Enterococci and Enterobacteria [10, 15]. Reduced biodiversity associated with chronic antibiotic use, inflammatory diseases and aging may result in colonization of toxin-producing Clostridium difficile bacterium. These changes lead to an alteration of gut immune cell composition creating a state of low-grade chronic inflammation. In addition, there is loss of protective factors, such as mucus, immunoglobulins and other antimicrobial protective peptides, such as bacteriocins. Dysbiosis is also implicated with other chronic diseases associated with aging. These include increased susceptibility to respiratory infections, inflammatory bowel disease, chronic inflammation, arthritis and also malignancy of the bowel [15, 46-48].

In addition, intestinal dysbiosis is also implicated in progression of malignancy and resistance to anticancer immunotherapy. These effects occur due to modulation of the immune system [49, 50]. Further dysbiosis, through diet and aging and associated medical diseases, such as COPD, chronic inflammation and antibiotics, are linked with altered immune responses and homeostasis in the airways [51].

Induction of a pro-inflammatory T-cell response by microorganisms can elicit development of T-helper-1 (Th1), Th2, or Th17 cells [28]. Pro-inflammatory T-cell helper and cytotoxic responses are suppressed by the action of various subsets of regulatory $\mathrm{T}$ cells (Treg) [13, 52]. Loss of 
gut mucosal membrane integrity, loss of tight junction and leaky gut phenomenon lead to activation of local PAMP molecules. Pattern recognition receptors, such as TLR, NOD recognize these molecules and activate inflammasomes with IL-6, IL-17, TNF release, causing oxidative stress and release of ROS [52, 53].

There is evidence that dysbiosis may be relevant in systemic SARS-CoV-2 infections.

Yeoh et al. demonstrated in their cohort of 100 patients that composition of gut microbiome in patients with COVID-19 correlated with disease severity and plasma concentrations of several inflammatory cytokines, chemokines associated with tissue damage (TNF- $\alpha$, CXCL10, CCL2 and IL-10, C-reactive protein, lactate dehydrogenase, aspartate aminotransferase and gamma-glutamyl transferase.). Patients with COVID-19 were depleted of beneficial microbiome with immunomodulatory potential, such as Faecalibacterium prausnitzii, Eubacterium rectale and several Bifidobacterium species and the dysbiosis persisted after the clearance of the virus [54].

In another cohort, $\mathrm{Gu}$ et al. compared healthy controls with COVID-19 patients by $16 \mathrm{~S}$ rDNA gene sequencing of fecal samples. COVID-19 patients had a significantly reduced bacterial diversity with higher abundance of opportunistic pathogens, such as Streptococcus, Rothia, Veillonella and Actinomyces, and a lower relative abundance of beneficial symbionts. These patients also had a significantly higher level of IL- 6 and TNF- $\alpha$, CRP and significantly lower lymphocyte count, markers for severity and mortality [55].

Similarly, Khan et al. demonstrated an association of dysbiosis with severe inflammatory response. Suppressed Firmicutes /Bacteroidetes ratio, caused by the depletion of the fiber-utilizing bacteria $F$. prausnitzii, B. Plebius, and Prevotella, and a relative increase in Bacteroidetes species is associated elevated serum IL-21 levels. However, they did not elaborate on the temporal association of the inflammatory markers with the stool samples. Elevated IL-21 level early in viral infections is beneficial and is cytotoxic to the infected cells, however, a delayed response is detrimental as observed in COVID-19 infections [56].

In an NIH-funded study, Venzon et al. demonstrate a link between SARS-CoV-2 infection, gut microbiome dysbiosis, and bloodstream infections. The loss of microbiome diversity and Faecalibacterium in patients with severe COVID19 infection mirrored a similar loss of diversity in mice inoculated with high doses of SARS-CoV-2. Stool samples of 101 COVID-19 patients at two different clinical sites revealed substantial gut microbiome dysbiosis, paralleling observations in the animal model. This analysis revealed that genus Faecalibacterium was negatively associated with blood stream infection (OR -1.49 , CI $[-2.82,-0.18]$ ). Analysis of blood culture results with paired microbiome data obtained from these patients suggests that bacteria translocate from the gut into the systemic circulation of COVID-19 patients [57].

Tang et al. in their cohort of 57 patients with COVID-19 with varying severity indicated that dysbiosis occurred in COVID-19 patients and changes in the gut microbiome was associated with disease severity and hematological parameters. The butyrate-producing bacteria, Faecalibacterium prausnitzii, Clostridium butyricum, Clostridium leptum, and Eubacterium rectale, decreased significantly in severe patients. This was accompanied by an increase in the opportunistic pathogens Enterococcus, Enterobacteriaceae [58].

Similarly, Moreira-Rosário et al. in their cohort on 115 patients demonstrated the gut microbiota of moderate and severe patients have a lower Firmicutes/Bacteroidetes ratio, predominance of Proteobacteria and lower abundance of beneficial butyrate-producing bacteria. Multivariable regression analysis showed that the Shannon diversity index [odds ratio (OR) 2.85, 95\% CI 1.09-7.41, $p=0.032$ ) and C-reactive protein (OR 3.45, 95\% CI 1.33-8.91, $p=0.011)$ are risk factors for severe COVID-19 [59].

Collectively, these data suggest that loss of butyrateproducing obligate anaerobes in the gut may increase the severity of COVID-19-related sepsis and involve a state of systemic hyper-inflammation with its un-intended consequences, such as generalized hypoxia and mucosal ischemia. Sepsis causes structural and functional changes in the mucosa of the GI tract, such as loss of mucus, barrier integrity, change in microbiome and risk of translocation. In addition, there may be direct mucosal SARS-CoV-2 viral infection through the blood viremia or swallowed virus. As mentioned earlier, SARS-CoV-2 has been detected in feces implicating either an active infection or asymptomatic viral shedding [40, 41, 60]. This systemic hyper-inflammatory state when combined with dysfunction of GI tract may overwhelm the body's ability to recover from cytokine storm.

Therefore, a healthy baseline microbiota of the GI tract may be necessary and may have beneficial effects in a population if they get infected with SARS-CoV-2 virus. The mechanism by which gut microbiota modulates the immune system is varied and includes a combination of pro-inflammatory and anti-inflammatory function. Gut microbiome produce diverse metabolites from the anaerobic fermentation of exogenous undigested dietary components. One such group of molecules is short-chain fatty acids (SCFAs) - such as butyrate, propionic acid and acetic acid. These are produced by microbial fermentation of undigested or partially digested dietary fiber and have broad effects on epithelial barrier and host immune system function $[8,61]$. It promotes production of mucus, secretion of secretory IgA to enhance local immunity. SCFA also inhibits NF-KB activity and downstream activation of inflammasommes and cytokines [61]. There is upregulation of colonic regulatory $\mathrm{T}$ (Treg) cells and their production of anti-inflammatory cytokines, 
such as transforming growth factor- $\beta$ (TGF $\beta$ ) and IL- 10 , to maintain a delicate balance between homeostasis and tolerance [52, 53, 61-63]. Other functions of SCFA include activating and facilitating migration of DC cells at sites of inflammation and infection. Activated DC cells as described earlier, are vital as an antiviral defense mechanism by releasing IFN in COVID-19 sepsis [52, 53, 61, 62]. SCFA activities also effect cell metabolism and may also inhibit transcription of genes by inhibiting histone deacetylase (HDAC) activity [63]. SCFA activity is also implicated in gut-lung axis as these microbial products may circulate systemically to the airway epithelium and alter inflammation locally in airway epithelium. Increased circulating levels of SCFAs lead to enhanced generation of dendritic cell precursors through bone marrow hematopoiesis and subsequent seeding of lungs by DCs with high antiviral and primary defense capacity [64].

Other molecules derived from microbiome with antiinflammatory activity in the GI tract are sphingolipids, ceramides and polysaccharides. Microbiome-derived sphingolipids, demonstrate stimulation of DC to increase expansion of virus-specific T-cells upon viral infections [65]. Polysaccharide A (PSA) suppresses inflammation by upregulating activity of colonic regulatory $\mathrm{T}$ (Treg) cells, and boosting their production of anti-inflammatory cytokines $[52,66]$.

Other effects of gut dysbiosis include loss of mucosal integrity and antecedent risk for translocation of lipopolysaccharides (LPS) which are derived from pathogenic Gramnegative bacteria. This commonly occurs in sepsis with generalized tissue hypo-perfusion leading to gut mucosal ischemia and loss of barrier function. LPS triggers activation of toll-like receptor (TLR4) and its downstream signaling pathways manifested as a cytokine storm $[67,68]$.

There is sufficient evidence that probiotics defined as live non-pathogenic, microbial ingredients when consumed in sufficient quantities, have health benefits. They have immunomodulatory properties and are strain-dependent. For example, introduction of probiotic strains, such as Bifidobacterium lactis, results in a significant increase in the proportion of mononuclear leukocytes, and enhances the activity of NK cells [10, 15, 69] Majority of probiotics consist of Lactobacillus, Bifidobacterium, Saccharomyces and may offer protection in COVID-19 sepsis.

Zhang et al. reported a propensity score-matched retrospective study evaluating probiotics and outcomes in 375 adult patients with COVID-19, 179 cases (probiotics group) and the other 196 cases (non-probiotics group) were included. The primary outcome was clinical improvement which was compared among propensity-score-matched groups and an unmatched cohort. Secondary outcomes included the duration of viral shedding, fever, and hospital stay. Among the propensity-score-matched groups, probiotics was related to clinical improvement rates (log-rank $p=0.028)$. This relationship was driven primarily by a shorter (days) time to clinical improvement [difference, -3 $(-4$ to -1$), p=0.022]$, reduction in duration of fever $[-1.0$ ( -2.0 to 0.0$), p=0.025]$, viral shedding [ $-3(-6$ to -1$)$, $p<0.001]$, and hospital stay [ $-3(-5$ to -1$), p=0.009$ ]. However, the limitations were, this study was a retrospective propensity-matched and not a prospective study, single institution in Shenzhen and critically ill patients were underrepresented [70].

A recent pilot study on fifteen patients by Zhou et al., shed insight into association between intestinal dysbiosis and GI epithelial ACE-2 levels and severity of COVID-19 [71]. Increased Coprobacillus and pathogenic Clostridium species with concomitant decrease in Faecalibacterium prausnitzii correlated with increased severity of COVID-19 sepsis. Another observation of this study was that Bacteroides species downregulated the expression of angiotensinconverting enzyme 2 (ACE2) and correlated inversely with SARS-CoV-2 load in fecal samples from patients [71].

It has been demonstrated that SARS-CoV-2 binds to human angiotensin-converting enzyme 2 (ACE-2) to infect the host cell and is vital step for entry into the cell $[72,73]$. In addition to virus entry, this process also leads to downregulation of anti-inflammatory ACE2 expression, thereby causing excessive generation of pro-inflammatory Angiotensin II via the enzyme ACE [74]. The renin-angiotensin system (RAS) is a critical homeostasis regulatory system in the human physiology. The ACE-Angiotensin II-AT1R pathway is called the classical RAS axis and is vital for various normal physiological functions, while the ACE2-Angiotensin1-7-MasR signaling is called the counter-regulatory RAS axis pathway, and is equally important for negative regulatory role and anti-inflammatory activity $[75,76]$. The primary role of RAS axis is to stimulate the sympathetic nervous system causing vasoconstriction and maintain the vascular tone and blood pressure. However, with chronic overstimulation, they cause unintended deleterious side effects of inflammation, oxidative stress, atherosclerosis, migration of endothelial cells and vascular smooth muscle cells, fibrosis, and myocardial hypertrophy. The negative regulatory axis mediated by ACE2 can antagonize these effects. ACE2 levels decline with aging and so does its protective effect on many of organ systems [70, 76, 77].

The interaction between dysbiosis and ACE-2 enzyme activity in GI tract remains poorly understood. ACE-2 is expressed on the epithelium of GI tract and also other epithelial surfaces [78]. Deficiencies in murine (ACE-2) knock out studies have demonstrated increased susceptibility to dysbiosis and intestinal inflammation and colitis, induced by epithelial damage [79]. Fecal transplantation of the altered microbiota from mutant ACE-2 knock out mice into germ-free wild-type was able to transmit this increased susceptibility to develop severe colitis. Hashimoto et al. 
demonstrated the possible anti-inflammatory role of ACE-2 enzyme activity in GI tract through amino acid hemostasis. ACE2-dependent changes in epithelial immunity and gut microbiota can be directly regulated by dietary amino acid tryptophan [80]. Similarly, other authors have also suggested an RAS-independent protective mechanism of ACE-2 expression, such as alteration in intestinal amino acid transporter function, tryptophan uptake, expression of antimicrobial peptides, and changing the ecology of the gut microbiome [79, 81]. Elderly patients with decreased ACE-2 levels and deregulated (overactive) RAS axis as depicted with hypertension, diabetes and kidney disease have increased risk for dysbiosis and this incidentally remains as a factor in elevated morbidity and mortality associated with COVID-19 sepsis $[70,76,77]$.

Vit $\mathrm{D}$, in addition to its function in bone and mineral metabolism has an essential immunomodulatory function in innate and adaptive immune responses to viral infection [82]. Anti-inflammatory functions of Vit $\mathrm{D}$ include regulation of gut microbiome and maintaining microbial diversity. Vit D promotes growth of gut-friendly commensal strains of Bifida and Fermicutus species. Vit D and its receptor (VDR) deficiency results in dysbiosis, leaky guts resulting in chronic, low-grade inflammation in the gastrointestinal tract and is implicated as an etiology in inflammatory bowel disease [83, 84]. In addition, Vit $\mathrm{D}$ also regulates microbial complexity, maintains cell junctions and barrier function and the mucosal immune responses to ensure intestinal homeostasis [83]. Vit D along with other nutrient factors acts in synergy to regulate $\mathrm{ZO}-1$, occludin and claudin tight junction proteins. These are key proteins essential for the integrity and intact intestinal barrier [83].

Vit $D$ plays a key role in initial antiviral and a subsequent anti-inflammatory (immune tolerance) phase in the COVID19 sepsis [77, 83, 85, 86]. Vit $\mathrm{D}$ is essential in attenuating cytokine storm by decreasing the TNF- $\alpha / \mathrm{NF}_{5} \mathrm{~B}$ and IFN- $\gamma$, IL-6 activity and also modulating adaptive immunity by suppressing $\mathrm{T}$ helper cell type 1 response and promoting $\mathrm{T}$ regulatory cell function [83, 84]. In Vit D-deficient states, there is an increased ratio of cytotoxic $\mathrm{T}$ lymphocytes and reduced TREG lymphocytes.

In addition, Vit $\mathrm{D}$ is a negative regulator for expression of renin and its production and interacts with the RAS/ ACE/ ACE-2 signaling axis. Vit D deficiency leads to an upregulation of RAS/ACE signaling and pro-inflammatory activity. This may enhance the severity in COVID-19 sepsis with clinical features of ARDS, pulmonary edema, cardiovascular injury and thrombotic events $[77,87]$.

Immune cells have a key role in the synthesis of active form of Vit D and are also a target for its effects. They activate the hormone and aid the local immune function in an autocrine or a paracrine fashion. There is evidence that antigen-presenting cells (APC), such as macrophages and dendritic cells, synthesize the active form of Vit D, 1,25-dihydroxyvitamin $\mathrm{D}\left(1,25(\mathrm{OH})_{2} \mathrm{D}\right)$ from its precursor 25-hydroxyvitamin D (25-OHD) via the enzyme $1 \alpha$-hydroxylase (CYP27B1) [85, 86]. Active form of Vit D and its receptor expression are regulated during differentiation of human monocytes into macrophages and may be crucial for effective function of the primary antigen-presenting immune cells against invading pathogens [85, 88].

Normal level of active forms of Vit D levels is critically dependent upon1 $\alpha$-hydroxylase (CYP27B1), a mitochondrial cytochrome $\mathrm{P} 450$ enzyme that catalyzes the conversion of inactive precursor of Vit $\mathrm{D}$ to active metabolite $1 \propto 25(\mathrm{OH})_{2} \mathrm{D}_{3}$. This 1-hydroxylase enzymatic activity is localized to mitochondrial inner membranes and may decline in immune-senescent cells $[89,90]$. In addition to the immune cells, the enzyme $1 \alpha$-hydroxylase (CYP27B1) is also expressed in the epithelium of the respiratory and GI tract [90].

Vit $\mathrm{D}$, thus has an essential role in complex interaction in maintaining GI homeostasis, gut microbiome, RAS/ ACE/ ACE-2 signaling, differentiation and function of immune cells and innate, humoral, and cellular immune responses. The beneficial effects of Vit D supplementation in viral infections remain unclear. A prior pooled meta-analysis study of 11,321 participants from 25 randomized controlled trials demonstrated that Vit D supplementation protected against acute respiratory tract infections. Oral supplementation in patients with very low serum levels $(<25 \mathrm{nmol} / \mathrm{L})$ of 25-hydroxyvitamin D concentrations, was demonstrated as safe and protected against acute respiratory tract infection [91]. The recent COVID-19 pandemic has demonstrated the high morbidity and mortality in the elderly patients and the minorities (dark skinned) in the countries of northern latitude compared to similar population in the southern latitudes. This observational and circumstantial evidence has suggested that long winters, remaining indoors, less exposure to sunlight and inadequate absorption of Vit D from the sunlight leads to deficiencies and may remain an essential factor [92].

Although promising the evidence of Vitamin D supplementation in acute COVID-19 infection remains inconsistent and insufficient in reducing the probability of ICU admission, inflammation, hospitalization, and pulmonary involvement. In a metanalysis by Kazemi et al. on 39 retrospective and prospective cohort, cross-sectional, case-control, and randomized controlled trial studies to assess the relation between 25D status and SARS-CoV-2 infection as well as COVID-19 severity. Overall, the researchers noted a greater risk of SARS-CoV-2 infection in the Vitamin D-deficient group. However, the studies were heterogeneous in methodological and statistical approach, and with many confounding variables, such as age, sex and ethnicity, diet, sunshine, 
lifestyle choices and caution should be exercised in interpreting these results [93].

In addition, a randomized controlled trial on 240 COVID19 patients with moderate to severe COVID-19, a single oral dose of $200,000 \mathrm{IU}$ of vitamin $\mathrm{D}_{3}$, compared to placebo, did not significantly reduce the duration of hospitalization (median of 7.0 vs 7.0 days; unadjusted hazard ratio for hospital discharge, 1.07) and did not support the use of a high dose of vitamin $\mathrm{D}_{3}$ for treatment of moderate to severe infection [94]. Currently, a large number of trials on benefits of Vitamin D in COVID-19 are being conducted at multiple international centers. Their details can be accessed at www. clinicaltrials.gov and results are awaited.

There also is some evidence that Vit D may have salutary influence in response to immunization. However, most studies reporting on the favorable effects of Vit D on vaccine responses have investigated responses to influenza vaccination and the results are conflicting [95]. Patients with renal failure on hemodialysis receiving parenteral calcitriol treatment may respond with higher antibody responses for influenza, Hepatitis B and tetanus vaccines [95].

\section{Inflammaging, immune-senescence, immune health of the gut and vaccination in elderly}

Efficacy and robustness of vaccinations are suboptimal in elderly compared to children and younger population. As described, immuno-senescence and inflammaging may collectively diminish the immune responses and ability to fight infections in elderly. There is growing evidence that ageassociated immune-senescence and inflammaging also have a detrimental effect on vaccine response in elderly $[6,18$, 96]. Aging and decline in naive T cells may be risk factors for failure to generate a coordinated immune response, resulting in increased susceptibility to severe COVID-19 [97]. Elderly patients also have a rapid decline in antibodies to vaccinations and frequently need a booster dose to sustain levels of antibodies. For example, the ability of influenza vaccine to induce protection is age-related, with an efficacy between 70 and $90 \%$ in children and young adults, but reduces to 30-50\% for those over 65 years $[11,98]$. Profiles predicting successful vaccination response to influenza vaccination, correlated with positive expression of genes associated with T-cell and B-cell function while monocyte (TLR4, TLR8, NOD2, and ASGR2) pattern recognition receptors involved in innate immunity and inflammation-related genes encoding (IFN- $\gamma$, IL-13R, TIMP2, LYN, SYK) negatively correlated with influenza-specific antibody responses, supporting the concept that inflammatory responses (inflammaging and immune-senescence) at baseline might be detrimental to vaccine-induced antibody responses [14, 45, 99].

In addition, older patients with immune-senescent lymphocytes may fail to mount a robust antibody response to newer virus and vaccines $[19,96]$ A clue to this possibility has emerged with recent reports of COVID-19 recurrences in a few patients getting re-infected by the variants of virus and due to waning of natural antibody response $[1,2,100$, 101]. Some of the re-infected patients suffered mild symptoms but other presented with severe symptoms on reinfection. This discrepancy and likely variation in immunological memory is a cause of concern in the vaccine and antibody therapies. Age-related changes in antigen uptake by APCs, loss of naïve lymphocytes, processing and presentation to MHC, as well as recognition and functional defects of B and T cells, may lead to reduced antibody responses [19]. This problem is especially worrisome in the setting of current SARS-CoV-2 pandemic, wherein the majorities of patients are elderly and have demonstrated the highest mortality regardless of comorbidities or ethnicity. Although promising with greater than $90 \%$ efficacy, the currently available COVID-19 vaccine-induced antibody response may be short-lived and wane in the elderly and remains to be noted.

The immunomodulatory property of probiotics may influence the response to vaccines [15, 43, 44]. A meta-analysis of nine RCTs including 623 participants, suggested that probiotics and prebiotics are effective in elevating immunogenicity by influencing seroconversion and protection rates in adults administered influenza vaccines. Participants who took probiotics or prebiotics showed significant improvements in the $\mathrm{H} 1 \mathrm{~N} 1$ strain protection rate [odds ratio (OR) $1.83,95 \%$ confidence interval (CI) $1.19-2.82, p=0.006$ ], the $\mathrm{H} 3 \mathrm{~N} 2$ strain protection rate (OR 2.85, 95\% CI 1.59-5.10, $p<0.001)$ and the $\mathrm{B}$ strain seroconversion rate (OR 2.11, 95\% CI 1.38-3.21, $p<0.001$ ) [102]. Another meta-analysis evaluated 3812 patients from 26 different studies found a beneficial effect of probiotics. The evidence for a beneficial effect of probiotics on vaccine response was strongest for oral vaccinations for non-respiratory infections and for parenteral influenza vaccination [103]. The gut-associated lymphoid tissues (GALTs) and complex interactions with microbiota may thus play an important role in the induction of antigen-specific immune responses in the gut [37, 104].

\section{Future directions}

This review suggest that, until there are effective antiviral medications for COVID-19 infections, simple adjunct interventions that modulate immune systems, such as use of probiotics and Vit $\mathrm{D}$, may offer protection to prevent severe sepsis in elderly and susceptible individuals. The underlying mechanisms can be harnessed for developing therapies that may offer some immune protection. The gut mucosal immune system along with its interaction through gut-lung axis may also be used to develop mucosal vaccines and can also be a candidate site for future vaccinations [44, 45, 104]. 
These adjunct therapies may improve vaccine efficacy and duration of protection for vaccinated individuals. However, there are certain challenges which need to be addressed. With advanced next-generation sequence technologies, such as meta-taxonomic, metabolomics, metagenomics and transcriptome analysis, along with multi-parametric high throughput flow cytometry, the gut microbiome can be characterized, and their resulting host humoral and cellular immune responses can also be studied. Advanced system biology and AI (artificial intelligence)-assisted integration could assist with correlation of the gut microbiome with vaccine responses [44]. Using machine learning models, Guo et al. demonstrated in their multi-omics analyses, a risk score based on 20 blood proteomic biomarkers, predicting severity of COVID-19 infection. They demonstrated that a core set of gut microbiota can predict the proteomic biomarkers among 301 individuals and these correlated with pro-inflammatory cytokines in another independent set of 366 individuals [105]. Fecal metabolomics analysis suggests potential amino acid-related pathways linking gut microbiota to host metabolism and inflammation. Similar data may be needed in other ethnic, sex and age groups. Further studies are needed on establishing optimal probiotic strains, doses of probiotics and Vit $\mathrm{D}$ and timing of administration in relation to disease and vaccinations.

\section{Conclusion}

To conclude, SARS-CoV-2 pandemic continues to spread erratically and has caused destruction in terms of the economy, health and wellbeing of the population. We are one year into the pandemic and there seems to be no clear therapy. Although there is hope that vaccinations may control this pandemic eventually, the majority of global population is currently un-immunized, and it is too early to determine any long-term protective antibody levels and efficacy. We have described the important functions of gut microbiome, Vit D, and ACE-2/RAS system interaction in COVID-19 infection. Modifying these factors may attenuate the severity of illness in infected population. Further research is needed in role of probiotics in maintaining long-term immunity and success with vaccines in SARS-CoV-2 infection.

Acknowledgements The author has no conflict of interest to disclose or any funding for this manuscript.

\section{References}

1. Bergwerk M, Gonen T, Lustig Y, Amit S, Lipsitch M, Cohen C, Mandelboim M, Gal Levin E, Rubin C, Indenbaum V, Tal I, Zavitan M, Zuckerman N, Bar-Chaim A, Kreiss Y,
Regev-Yochay G. Covid-19 breakthrough infections in vaccinated health care workers. N Engl J Med. 2021. https://doi. org/10.1056/NEJMoa2109072.

2. Brown CM, Vostok J, Johnson H, Burns M, Gharpure R, Sami S, Sabo RT, Hall N, Foreman A, Schubert PL, Gallagher GR, Fink T, Madoff LC, Gabriel SB, MacInnis B, Park DJ, Siddle KJ, Harik V, Arvidson D, Brock-Fisher T, Dunn M, Kearns A, Laney AS. Outbreak of SARS-CoV-2 infections, including COVID-19 vaccine breakthrough infections, associated with large public gatherings-Barnstable County, Massachusetts, July 2021. MMWR Morb Mortal Wkly Rep. 2021;70:1059-62. https://doi.org/10.15585/mmwr.mm7031e2.

3. Shenoy S. SARS-CoV-2 (COVID-19), viral load and clinical outcomes; lessons learned one year into the pandemic: a systematic review. World J Crit Care Med. 2021;10:132-50. https://doi.org/10.5492/wjccm.v10.i4.132.

4. Shenoy S. Coronavirus (Covid-19) sepsis: revisiting mitochondrial dysfunction in pathogenesis, aging, inflammation, and mortality. Inflamm Res. 2020;69:1077-85. https://doi.org/10. 1007/s00011-020-01389-z.

5. Polidori MC, Sies H, Ferrucci L, Benzing T. COVID-19 mortality as a fingerprint of biological age. Ageing Res Rev. 2021;67:101308. https://doi.org/10.1016/j.arr.2021.101308.

6. Franceschi C, Bonafè M, Valensin S, Olivieri F, De Luca M, Ottaviani E, De Benedictis G. Inflamm-aging. An evolutionary perspective on immunosenescence. Ann N Y Acad Sci. 2000;908:244-54. https://doi.org/10.1111/j.1749-6632.2000. tb06651.x.

7. Heel KA, McCauley RD, Papadimitriou JM, Hall JC. Review: Peyer's patches. J Gastroenterol Hepatol. 1997;12:122-36. https://doi.org/10.1111/j.1440-1746.1997.tb00395.x.

8. Belkaid Y, Hand TW. Role of the microbiota in immunity and inflammation. Cell. 2014;157:121-41. https://doi.org/10. 1016/j.cell.2014.03.011.

9. Aktas B, Aslim B. Gut-lung axis and dysbiosis in COVID19. Turk J Biol. 2020;44:265-72. https://doi.org/10.3906/ biy-2005-102.

10. Dhar D, Mohanty A. Gut microbiota and Covid-19-possible link and implications. Virus Res. 2020;285:198018. https:// doi.org/10.1016/j.virusres.2020.198018 (Epub 2020 May 13).

11. Ciabattini A, Nardini C, Santoro F, Garagnani P, Franceschi C, Medaglini D. Vaccination in the elderly: the challenge of immune changes with aging. Semin Immunol. 2018;40:83-94. https://doi.org/10.1016/j.smim.2018.10.010.

12. Aiello A, Farzaneh F, Candore G, Caruso C, Davinelli S, Gambino CM, Ligotti ME, Zareian N, Accardi G. Immunosenescence and its hallmarks: how to oppose aging strategically? A review of potential options for therapeutic intervention. Front Immunol. 2019;10:2247. https://doi.org/10.3389/fimmu. 2019.02247.

13. Bajaj V, Gadi N, Spihlman AP, Wu SC, Choi CH, Moulton VR. Aging, immunity, and COVID-19: how age influences the host immune response to coronavirus infections? Front Physiol. 2021;11:571416. https://doi.org/10.3389/fphys.2020.571416.

14. Pinti M, Appay V, Campisi J, Frasca D, Fülöp T, Sauce D, Larbi A, Weinberger B, Cossarizza A. Aging of the immune system: focus on inflammation and vaccination. Eur J Immunol. 2016;46:2286-301. https://doi.org/10.1002/eji.201546178.

15. Yaqoob P. Ageing, immunity and influenza: a role for probiotics? Proc Nutr Soc. 2014;73:309-17. https://doi.org/10.1017/S0029 665113003777 (Epub 2013 Dec 3).

16. Aspinall R, Del Giudice G, Effros RB, Grubeck-Loebenstein B, Sambhara S. Challenges for vaccination in the elderly. Immun Ageing. 2007;4:9. https://doi.org/10.1186/1742-4933-4-9.

17. Ponnappan S, Ponnappan U. Aging and immune function: molecular mechanisms to interventions. Antioxid Redox Signal. 
2011;14:1551-85. https://doi.org/10.1089/ars.2010.3228 (Epub 2011 Jan 8).

18. Fulop T, Larbi A, Hirokawa K, Cohen AA, Witkowski JM. Immunosenescence is both functional/adaptive and dysfunctional/maladaptive. Semin Immunopathol. 2020;42:521-36. https://doi.org/10.1007/s00281-020-00818-9 (Epub 2020 Sep 15).

19. Acharya D, Liu G, Gack MU. Dysregulation of type I interferon responses in COVID-19. Nat Rev Immunol. 2020;20:397-8. https://doi.org/10.1038/s41577-020-0346-x (Epub 2020 May 26).

20. Shaw AC, Goldstein DR, Montgomery RR. Age-dependent dysregulation of innate immunity. Nat Rev Immunol. 2013;13:87587. https://doi.org/10.1038/nri3547 (Epub 2013 Oct 25).

21. Gordon DE, Jang GM, Bouhaddou M, Xu J, Obernier K, White KM, O’Meara MJ, Rezelj VV, Guo JZ, Swaney DL, Tummino TA, Hüttenhain R, Kaake RM, Richards AL, Tutuncuoglu B, Foussard H, Batra J, Haas K, Modak M, Kim M, Haas P, Polacco BJ, Braberg H, Fabius JM, Eckhardt M, Soucheray M, Bennett MJ, Cakir M, McGregor MJ, Li Q, Meyer B, Roesch F, Vallet T, Mac Kain A, Miorin L, Moreno E, Naing ZZC, Zhou Y, Peng S, Shi Y, Zhang Z, Shen W, Kirby IT, Melnyk JE, Chorba JS, Lou K, Dai SA, Barrio-Hernandez I, Memon D, Hernandez-Armenta C, Lyu J, Mathy CJP, Perica T, Pilla KB, Ganesan SJ, Saltzberg DJ, Rakesh R, Liu X, Rosenthal SB, Calviello L, Venkataramanan S, Liboy-Lugo J, Lin Y, Huang XP, Liu Y, Wankowicz SA, Bohn M, Safari M, Ugur FS, Koh C, Savar NS, Tran QD, Shengjuler D, Fletcher SJ, O'Neal MC, Cai Y, Chang JCJ, Broadhurst DJ, Klippsten S, Sharp PP, Wenzell NA, Kuzuoglu-Ozturk D, Wang HY, Trenker R, Young JM, Cavero DA, Hiatt J, Roth TL, Rathore U, Subramanian A, Noack J, Hubert M, Stroud RM, Frankel AD, Rosenberg OS, Verba KA, Agard DA, Ott M, Emerman M, Jura N, von Zastrow M, Verdin E, Ashworth A, Schwartz O, d'Enfert C, Mukherjee S, Jacobson M, Malik HS, Fujimori DG, Ideker T, Craik CS, Floor SN, Fraser JS, Gross JD, Sali A, Roth BL, Ruggero D, Taunton J, Kortemme T, Beltrao P, Vignuzzi M, García-Sastre A, Shokat KM, Shoichet BK, Krogan NJ. A SARS-CoV-2 protein interaction map reveals targets for drug repurposing. Nature. 2020;583:459-68. https://doi.org/10. 1038/s41586-020-2286-9 (Epub 2020 Apr 30).

22. Lei X, Dong X, Ma R, Wang W, Xiao X, Tian Z, Wang C, Wang Y, Li L, Ren L, Guo F, Zhao Z, Zhou Z, Xiang Z, Wang J. Activation and evasion of type I interferon responses by SARSCoV-2. Nat Commun. 2020;11:3810. https://doi.org/10.1038/ s41467-020-17665-9.

23. Kopecky-Bromberg SA, Martínez-Sobrido L, Frieman M, Baric RA, Palese P. Severe acute respiratory syndrome coronavirus open reading frame (ORF) 3b, ORF 6, and nucleocapsid proteins function as interferon antagonists. J Virol. 2007;81:548-57. https://doi.org/10.1128/JVI.01782-06 (Epub 2006 Nov 15).

24. Zhou R, To KK, Wong YC, Liu L, Zhou B, Li X, Huang H, Mo Y, Luk TY, Lau TT, Yeung P, Chan WM, Wu AK, Lung KC, Tsang OT, Leung WS, Hung IF, Yuen KY, Chen Z. Acute SARS-CoV-2 infection impairs dendritic cell and $\mathrm{T}$ cell responses. Immunity. 2020;53:864-877.e5. https://doi.org/10.1016/j.immuni.2020.07. 026 (Epub 2020 Aug 4).

25. Blanco-Melo D, Nilsson-Payant BE, Liu WC, Uhl S, Hoagland D, Møller R, Jordan TX, Oishi K, Panis M, Sachs D, Wang TT, Schwartz RE, Lim JK, Albrecht RA, tenOever BR. Imbalanced host response to SARS-CoV-2 drives development of COVID-19. Cell. 2020;181:1036-1045.e9. https://doi.org/10. 1016/j.cell.2020.04.026 (Epub 2020 May 15).

26. Hadjadj J, Yatim N, Barnabei L, Corneau A, Boussier J, Smith $\mathrm{N}$, Péré H, Charbit B, Bondet V, Chenevier-Gobeaux C, Breillat P, Carlier N, Gauzit R, Morbieu C, Pène F, Marin N, Roche N, Szwebel TA, Merkling SH, Treluyer JM, Veyer D, Mouthon
L, Blanc C, Tharaux PL, Rozenberg F, Fischer A, Duffy D, Rieux-Laucat F, Kernéis S, Terrier B. Impaired type I interferon activity and inflammatory responses in severe COVID-19 patients. Science. 2020;369:718-24. https://doi.org/10.1126/ science.abc6027 (Epub 2020 Jul 13).

27. De Biasi S, Meschiari M, Gibellini L, Bellinazzi C, Borella R, Fidanza L, Gozzi L, Iannone A, Lo Tartaro D, Mattioli M, Paolini A, Menozzi M, Milić J, Franceschi G, Fantini R, Tonelli R, Sita M, Sarti M, Trenti T, Brugioni L, Cicchetti L, Facchinetti F, Pietrangelo A, Clini E, Girardis M, Guaraldi G, Mussini C, Cossarizza A. Marked T cell activation, senescence, exhaustion and skewing towards TH17 in patients with COVID-19 pneumonia. Nat Commun. 2020;11:3434. https://doi.org/10. 1038/s41467-020-17292-4.

28. Wang J, Li F, Wei H, Lian ZX, Sun R, Tian Z. Respiratory influenza virus infection induces intestinal immune injury via microbiota-mediated Th17 cell-dependent inflammation. J Exp Med. 2014;211:2397-410. https://doi.org/10.1084/jem.20140 625 ((Erratum in: J Exp Med. 2014; 211:2396-7).

29. Schulz AR, Mälzer JN, Domingo C, Jürchott K, Grützkau A, Babel N, Nienen M, Jelinek T, Niedrig M, Thiel A. Low thymic activity and dendritic cell numbers are associated with the immune response to primary viral infection in elderly humans. J Immunol. 2015;195:4699-711. https://doi.org/10. 4049/jimmunol.1500598 (Epub 2015 Oct 12).

30. ElTanbouly MA, Noelle RJ. Rethinking peripheral T cell tolerance: checkpoints across a T cell's journey. Nat Rev Immunol. 2021;21:257-67. https://doi.org/10.1038/s41577-020-00454-2 (Epub 2020 Oct 19).

31. Patrick M, Weng NP. Expression and regulation of telomerase in human $\mathrm{T}$ cell differentiation, activation, aging and diseases. Cell Immunol. 2019;345:103989. https://doi.org/10.1016/j. cellimm.2019.103989 (Epub 2019 Sep 19).

32. Fülöp T, Larbi A, Pawelec G. Human T cell aging and the impact of persistent viral infections. Front Immunol. 2013;4:271. https://doi.org/10.3389/fimmu.2013.00271.

33. Diao B, Wang C, Tan Y, Chen X, Liu Y, Ning L, Chen L, Li M, Liu Y, Wang G, Yuan Z, Feng Z, Zhang Y, Wu Y, Chen $\mathrm{Y}$. Reduction and functional exhaustion of $\mathrm{T}$ Cells in patients with coronavirus disease 2019 (COVID-19). Front Immunol. 2020;11:827. https://doi.org/10.3389/fimmu.2020.00827.

34. Pinti M, Cevenini E, Nasi M, De Biasi S, Salvioli S, Monti D, Benatti S, Gibellini L, Cotichini R, Stazi MA, Trenti T, Franceschi C, Cossarizza A. Circulating mitochondrial DNA increases with age and is a familiar trait: implications for “inflamm-aging." Eur J Immunol. 2014;44:1552-62. https:// doi.org/10.1002/eji.201343921 (Epub 2014 Feb 13).

35. Burtscher J, Cappellano G, Omori A, Koshiba T, Millet GP. Mitochondria: in the cross fire of SARS-CoV-2 and immunity. iScience. 2020;23:101631. https://doi.org/10.1016/j.isci.2020. 101631 (Epub 2020 Sep 29).

36. Picca A, Lezza AMS, Leeuwenburgh C, Pesce V, Calvani R, Landi F, Bernabei R, Marzetti E. Fueling inflamm-aging through mitochondrial dysfunction: mechanisms and molecular targets. Int J Mol Sci. 2017;18:933. https://doi.org/10.3390/ ijms 18050933 .

37. Lamichhane A, Azegamia T, Kiyonoa H. The mucosal immune system for vaccine development. Vaccine. 2014;32:6711-23. https://doi.org/10.1016/j.vaccine.2014.08.089.

38. Burr AHP, Bhattacharjee A, Hand TW. Nutritional modulation of the microbiome and immune response. J Immunol. 2020;205:1479-87. https://doi.org/10.4049/jimmunol.2000419.

39. Esterházy D, Canesso MCC, Mesin L, Muller PA, de Castro TBR, Lockhart A, ElJalby M, Faria AMC, Mucida D. Compartmentalized gut lymph node drainage dictates adaptive immune 
responses. Nature. 2019;569:126-30. https://doi.org/10.1038/ s41586-019-1125-3 (Epub 2019 Apr 15).

40. Wang Y, Zhang L, Sang L, Ye F, Ruan S, Zhong B, Song T, Alshukairi AN, Chen R, Zhang Z, Gan M, Zhu A, Huang Y, Luo L, Mok CKP, Al Gethamy MM, Tan H, Li Z, Huang X, Li F, Sun J, Zhang Y, Wen L, Li Y, Chen Z, Zhuang Z, Zhuo J, Chen C, Kuang L, Wang J, Lv H, Jiang Y, Li M, Lin Y, Deng Y, Tang L, Liang J, Huang J, Perlman S, Zhong N, Zhao J, Malik Peiris JS, Li Y, Zhao J. Kinetics of viral load and antibody response in relation to COVID-19 severity. J Clin Invest. 2020;130:5235-44. https://doi.org/10.1172/JCI138759.

41. Magleby R, Westblade LF, Trzebucki A, Simon MS, Rajan M, Park J, Goyal P, Safford MM, Satlin MJ. Impact of SARS-CoV-2 viral load on risk of intubation and mortality among hospitalized patients with coronavirus disease 2019. Clin Infect Dis. 2020. https://doi.org/10.1093/cid/ciaa851.

42. Sette A, Crotty S. Adaptive immunity to SARS-CoV-2 and COVID-19. Cell. 2021;184:861-80. https://doi.org/10.1016/j. cell.2021.01.007 (Epub 2021 Jan 12).

43. Vlasova AN, Takanashi S, Miyazaki A, Rajashekara G, Saif LJ. How the gut microbiome regulates host immune responses to viral vaccines. Curr Opin Virol. 2019;37:16-25. https://doi.org/ 10.1016/j.coviro.2019.05.001.

44. Ciabattini A, Olivieri R, Lazzeri E, Medaglini D. Role of the microbiota in the modulation of vaccine immune responses. Front Microbiol. 2019;10:1305. https://doi.org/10.3389/fmicb. 2019.01305.

45. Hosomi K, Kunisawa J. Impact of the intestinal environment on the immune responses to vaccination. Vaccine. 2020;38:6959_ 65. https://doi.org/10.1016/j.vaccine.2020.08.079 (Epub 2020 Sep 12).

46. Halfvarson J, Brislawn CJ, Lamendella R, Vázquez-Baeza Y, Walters WA, Bramer LM, D'Amato M, Bonfiglio F, McDonald D, Gonzalez A, McClure EE, Dunklebarger MF, Knight R, Jansson JK. Dynamics of the human gut microbiome in inflammatory bowel disease. Nat Microbiol. 2017;2:17004. https://doi.org/10. 1038/nmicrobiol.2017.4

47. Andréasson K, Alrawi Z, Persson A, Jönsson G, Marsal J. Intestinal dysbiosis is common in systemic sclerosis and associated with gastrointestinal and extraintestinal features of disease. Arthritis Res Ther. 2016;18:278. https://doi.org/10.1186/ s13075-016-1182-z.

48. Thevaranjan N, Puchta A, Schulz C, Naidoo A, Szamosi JC, Verschoor CP, Loukov D, Schenck LP, Jury J, Foley KP, Schertzer JD, Larché MJ, Davidson DJ, Verdú EF, Surette MG, Bowdish DME. Age-associated microbial dysbiosis promotes intestinal permeability, systemic inflammation, and macrophage dysfunction. Cell Host Microbe. 2017;21:455-466.e4. https://doi.org/10. 1016/j.chom.2017.03.002 ((Erratum in: Cell Host Microbe. 2018 Apr 11;23 (4):570).

49. Buchta Rosean C, Feng TY, Azar FN, Rutkowski MR. Impact of the microbiome on cancer progression and response to anticancer therapies. Adv Cancer Res. 2019;143:255-94. https://doi. org/10.1016/bs.acr.2019.03.005 (Epub 2019 Apr 17).

50. Gopalakrishnan V, Helmink BA, Spencer CN, Reuben A, Wargo JA. The influence of the gut microbiome on cancer, immunity, and cancer immunotherapy. Cancer Cell. 2018;33:570-80. https://doi.org/10.1016/j.ccell.2018.03.015.

51. Dang AT, Marsland BJ. Microbes, metabolites, and the gut-lung axis. Mucosal Immunol. 2019;12:843-50. https://doi.org/10. 1038/s41385-019-0160-6 (Epub 2019 Apr 11).

52. Rooks MG, Garrett WS. Gut microbiota, metabolites and host immunity. Nat Rev Immunol. 2016;16:341-52. https://doi.org/ 10.1038/nri.2016.42.
53. Iddir M, Brito A, Dingeo G, Fernandez Del Campo SS, Samouda H, La Frano MR, Bohn T. Strengthening the immune system and reducing inflammation and oxidative stress through diet and nutrition: considerations during the COVID-19 crisis. Nutrients. 2020;12:1562. https://doi.org/10.3390/nu12061562.

54. Yeoh YK, Zuo T, Lui GC, Zhang F, Liu Q, Li AY, Chung AC, Cheung CP, Tso EY, Fung KS, Chan V, Ling L, Joynt G, Hui DS, Chow KM, Ng SSS, Li TC, Ng RW, Yip TC, Wong GL, Chan FK, Wong CK, Chan PK, Ng SC. Gut microbiota composition reflects disease severity and dysfunctional immune responses in patients with COVID-19. Gut. 2021;70:698-706. https://doi.org/ 10.1136/gutjnl-2020-323020.

55. Gu S, Chen Y, Wu Z, Chen Y, Gao H, Lv L, Guo F, Zhang X, Luo R, Huang C, Lu H, Zheng B, Zhang J, Yan R, Zhang H, Jiang $\mathrm{H}, \mathrm{Xu} \mathrm{Q}$, Guo J, Gong Y, Tang L, Li L. Alterations of the gut microbiota in patients with coronavirus disease 2019 or H1N1 influenza. Clin Infect Dis. 2020;71:2669-78. https://doi.org/10. 1093/cid/ciaa709.

56. Khan M, Mathew BJ, Gupta P, Garg G, Khadanga S, Vyas AK, Singh AK. Gut dysbiosis and IL-21 response in patients with severe COVID-19. Microorganisms. 2021;9:1292. https://doi. org/10.3390/microorganisms 9061292 .

57. Venzon M, Bernard-Raichon L, Klein J, Axelrad J, Hussey G, Sullivan A, Casanovas-Massana A, Noval M, Valero-Jimenez A, Gago J, Wilder E, Team YIR, Iwasaki A, Thorpe L, Littman D, Dittmann M, Stapleford K, Shopsin B, Torres V, Ko A, Cadwell $\mathrm{K}$, Schluter J. Gut microbiome dysbiosis during COVID-19 is associated with increased risk for bacteremia and microbial translocation. Res Sq. 2021. https://doi.org/10.21203/rs.3.rs-726620/ v1.

58. Tang L, Gu S, Gong Y, Li B, Lu H, Li Q, Zhang R, Gao X, Wu Z, Zhang J, Zhang Y, Li L. Clinical Significance of the correlation between changes in the major intestinal bacteria species and COVID-19 severity. Engineering (Beijing). 2020;6:1178-84. https://doi.org/10.1016/j.eng.2020.05.013 (Epub 2020 Jun 8).

59. Moreira-Rosário A, Marques C, Pinheiro H, Araújo JR, Ribeiro P, Rocha R, Mota I, Pestana D, Ribeiro R, Pereira A, de Sousa MJ, Pereira-Leal J, de Sousa J, Morais J, Teixeira D, Rocha JC, Silvestre M, Príncipe N, Gatta N, Amado J, Santos L, Maltez F, Boquinhas A, de Sousa G, Germano N, Sarmento G, Granja C, Póvoa P, Faria A, Calhau C. Gut microbiota diversity and C-reactive protein are predictors of disease severity in COVID19 patients. Front Microbiol. 2021;12:705020. https://doi.org/10. 3389/fmicb.2021.705020.

60. Cheung KS, Hung IFN, Chan PPY, Lung KC, Tso E, Liu R, Ng YY, Chu MY, Chung TWH, Tam AR, Yip CCY, Leung KH, Fung AY, Zhang RR, Lin Y, Cheng HM, Zhang AJX, To KKW, Chan KH, Yuen KY, Leung WK. Gastrointestinal manifestations of SARS-CoV-2 infection and virus load in fecal samples from a Hong Kong Cohort: systematic review and meta-analysis. Gastroenterology. 2020;159:81-95. https://doi.org/10.1053/j.gastro. 2020.03.065 (Epub 2020 Apr 3).

61. Chénard T, Prévost K, Dubé J, Massé E. Immune system modulations by products of the gut microbiota. Vaccines (Basel). 2020;8:461. https://doi.org/10.3390/vaccines8030461.

62. Samuelson DR, Welsh DA, Shellito JE. Regulation of lung immunity and host defense by the intestinal microbiota. Front Microbiol. 2015;6:1085. https://doi.org/10.3389/fmicb.2015. 01085.

63. Li M, van Esch BCAM, Wagenaar GTM, Garssen J, Folkerts G, Henricks PAJ. Pro- and anti-inflammatory effects of short chain fatty acids on immune and endothelial cells. Eur J Pharmacol. 2018;831:52-9. https://doi.org/10.1016/j.ejphar.2018.05.003 (Epub 2018 May 9). 
64. Trompette A, Gollwitzer ES, Yadava K, Sichelstiel AK, Sprenger N, Ngom-Bru C, Blanchard C, Junt T, Nicod LP, Harris NL, Marsland BJ. Gut microbiota metabolism of dietary fiber influences allergic airway disease and hematopoiesis. Nat Med. 2014;20:159-66. https://doi.org/10.1038/nm.3444 (Epub 2014 Jan 5).

65. Peng Y, Zhao J, Tun HM. The new foe and old friends: are we ready for microbiota-based therapeutics in treating COVID-19 patients? Gastroenterology. 2021;160:2192-3. https://doi.org/10. 1053/j.gastro.2020.08.048.

66. Telesford KM, Yan W, Ochoa-Reparaz J, Pant A, Kircher C, Christy MA, Begum-Haque S, Kasper DL, Kasper LH. A commensal symbiotic factor derived from Bacteroides fragilis promotes human CD39(+)Foxp3(+) T cells and Treg function. Gut Microbes. 2015;6:234-42. https://doi.org/10.1080/19490976. 2015.1056973.

67. Perrin-Cocon L, Aublin-Gex A, Sestito SE, Shirey KA, Patel MC, André P, Blanco JC, Vogel SN, Peri F, Lotteau V. TLR4 antagonist FP7 inhibits LPS-induced cytokine production and glycolytic reprogramming in dendritic cells, and protects mice from lethal influenza infection. Sci Rep. 2017;7:40791. https:// doi.org/10.1038/srep40791.

68. Gribar SC, Anand RJ, Sodhi CP, Hackam DJ. The role of epithelial Toll-like receptor signaling in the pathogenesis of intestinal inflammation. J Leukoc Biol. 2008;83:493-8. https://doi.org/10. 1189/jlb.0607358 (Epub 2007 Dec 26).

69. Gill HS, Darragh AJ, Cross ML. Optimizing immunity and gut function in the elderly. J Nutr Health Aging. 2001;5:80-91

70. Zhang L, Han H, Li X, Chen C, Xie X, Su G, Ye S, Wang C, He Q, Wang F, Huang F, Wang Z, Wu J, Lai T. Probiotics use is associated with improved clinical outcomes among hospitalized patients with COVID-19. Therap Adv Gastroenterol. 2021;14:17562848211035670. https://doi.org/10.1177/17562 848211035670.

71. Zuo T, Zhang F, Lui GCY, Yeoh YK, Li AYL, Zhan H, Wan Y, Chung ACK, Cheung CP, Chen N, Lai CKC, Chen Z, Tso EYK, Fung KSC, Chan V, Ling L, Joynt G, Hui DSC, Chan FKL, Chan PKS, Ng SC. Alterations in gut microbiota of patients with COVID-19 during time of hospitalization. Gastroenterology. 2020;159:944-9558. https://doi.org/10.1053/j.gastro.2020. 05.048 (Epub 2020 May 20).

72. Shang J, Ye G, Shi K, Wan Y, Luo C, Aihara H, Geng Q, Auerbach A, Li F. Structural basis of receptor recognition by SARSCoV-2. Nature. 2020;581:221-4. https://doi.org/10.1038/s41586020-2179-y (Epub 2020 Mar 30).

73. Hoffmann M, Kleine-Weber H, Schroeder S, Krüger N, Herrler T, Erichsen S, Schiergens TS, Herrler G, Wu NH, Nitsche A, Müller MA, Drosten C, Pöhlmann S. SARS-CoV-2 cell entry depends on ACE2 and TMPRSS2 and is blocked by a clinically proven protease inhibitor. Cell. 2020;181:271-280.e8. https://doi.org/10. 1016/j.cell.2020.02.052 (Epub 2020 Mar 5).

74. Verdecchia P, Cavallini C, Spanevello A, Angeli F. The pivotal link between ACE2 deficiency and SARS-CoV-2 infection. Eur J Intern Med. 2020;76:14-20. https://doi.org/10.1016/j.ejim.2020. 04.037 (Epub 2020 Apr 20).

75. Cheng H, Wang Y, Wang GQ. Organ-protective effect of angiotensin-converting enzyme 2 and its effect on the prognosis of COVID-19. J Med Virol. 2020;92:726-30. https://doi.org/10. 1002/jmv.25785 (Epub 2020 Apr 5).

76. Simões E, Silva AC, Teixeira MM. ACE inhibition, ACE2 and angiotensin-(1-7) axis in kidney and cardiac inflammation and fibrosis. Pharmacol Res. 2016;107:154-62. https://doi.org/10. 1016/j.phrs.2016.03.018 (Epub 2016 Mar 17).

77. Malek MA. A brief review of interplay between vitamin D and angiotensin-converting enzyme 2 : implications for a potential treatment for COVID-19. Rev Med Virol. 2020;30:e2119. https:// doi.org/10.1002/rmv.2119 (Epub 2020 Jun 25).

78. Zou X, Chen K, Zou J, Han P, Hao J, Han Z. Single-cell RNA-seq data analysis on the receptor ACE2 expression reveals the potential risk of different human organs vulnerable to 2019-nCoV infection. Front Med. 2020;14:185-92. https://doi.org/10.1007/ s11684-020-0754-0 (Epub 2020 Mar 12).

79. Viana SD, Nunes S, Reis F. ACE2 imbalance as a key player for the poor outcomes in COVID-19 patients with age-related comorbidities-role of gut microbiota dysbiosis. Ageing Res Rev. 2020;62:101123. https://doi.org/10.1016/j.arr.2020.101123 (Epub 2020 Jul 16).

80. Hashimoto T, Perlot T, Rehman A, Trichereau J, Ishiguro H, Paolino M, Sigl V, Hanada T, Hanada R, Lipinski S, Wild B, Camargo SM, Singer D, Richter A, Kuba K, Fukamizu A, Schreiber S, Clevers H, Verrey F, Rosenstiel P, Penninger JM. ACE2 links amino acid malnutrition to microbial ecology and intestinal inflammation. Nature. 2012;487:477-81. https://doi. org/10.1038/nature11228.

81. Cole-Jeffrey CT, Liu M, Katovich MJ, Raizada MK, Shenoy V. ACE2 and microbiota: emerging targets for cardiopulmonary disease therapy. J Cardiovasc Pharmacol. 2015;66:540-50. https:// doi.org/10.1097/FJC.0000000000000307.

82. Beard JA, Bearden A, Striker R. Vitamin D and the anti-viral state. J Clin Virol. 2011;50:194-200. https://doi.org/10.1016/j. jcv.2010.12.006 (Epub 2011 Jan 15).

83. Cantorna MT, Snyder L, Arora J. Vitamin A and vitamin D regulate the microbial complexity, barrier function, and the mucosal immune responses to ensure intestinal homeostasis. Crit Rev Biochem Mol Biol. 2019;54:184-92. https://doi.org/10.1080/ 10409238.2019.1611734 (Epub 2019 May 14).

84. Cantorna MT. Mechanisms underlying the effect of vitamin D on the immune system. Proc Nutr Soc. 2010;69:286-9. https:// doi.org/10.1017/S0029665110001722 (Epub 2010 Jun 2).

85. Hewison M. Vitamin D and the immune system: new perspectives on an old theme. Endocrinol Metab Clin N Am. 2010;39:365-79. https://doi.org/10.1016/j.ecl.2010.02.010.

86. Bilezikian JP, Bikle D, Hewison M, Lazaretti-Castro M, Formenti AM, Gupta A, Madhavan MV, Nair N, Babalyan V, Hutchings N, Napoli N, Accili D, Binkley N, Landry DW, Giustina A. mechanisms in endocrinology: Vitamin D and COVID-19. Eur J Endocrinol. 2020;183:R133-47. https://doi.org/10.1530/EJE-20-0665.

87. Ismailova $\mathrm{A}$, White $\mathrm{JH}$. Vitamin $\mathrm{D}$, infections and immunity. Rev Endocr Metab Disord. 2021. https://doi.org/10.1007/ s11154-021-09679-5.

88. Kreutz M, Andreesen R, Krause SW, Szabo A, Ritz E, Reichel H. 1,25-dihydroxyvitamin D3 production and vitamin D3 receptor expression are developmentally regulated during differentiation of human monocytes into macrophages. Blood. 1993;82:1300-7.

89. Hewison M, Freeman L, Hughes SV, Evans KN, Bland R, Eliopoulos AG, Kilby MD, Moss PA, Chakraverty R. Differential regulation of vitamin $\mathrm{D}$ receptor and its ligand in human monocyte-derived dendritic cells. J Immunol. 2003;170:5382-90. https://doi.org/10.4049/jimmunol.170.11.5382.

90. Hewison M, Zehnder D, Bland R, Stewart PM. 1alphaHydroxylase and the action of vitamin D. J Mol Endocrinol. 2000;25:141-8. https://doi.org/10.1677/jme.0.0250141.

91. Martineau AR, Jolliffe DA, Hooper RL, Greenberg L, Aloia JF, Bergman P, Dubnov-Raz G, Esposito S, Ganmaa D, Ginde AA, Goodall EC, Grant CC, Griffiths CJ, Janssens W, Laaksi I, Manaseki-Holland S, Mauger D, Murdoch DR, Neale R, Rees JR, Simpson S Jr, Stelmach I, Kumar GT, Urashima M, Camargo CA Jr. Vitamin D supplementation to prevent acute respiratory tract infections: systematic review and meta-analysis of individual participant data. BMJ. 2017;356:i6583. https://doi.org/10.1136/ bmj.i6583. 
92. Laird E, Rhodes J, Kenny RA. Vitamin D and inflammation: potential implications for severity of Covid-19. Ir Med J. 2020;113:81.

93. Kazemi A, Mohammadi V, Aghababaee SK, Golzarand M, Clark CCT, Babajafari S. Association of vitamin D status with SARSCoV-2 infection or COVID-19 severity: a systematic review and meta-analysis. Adv Nutr. 2021. https://doi.org/10.1093/advances/ nmab012.

94. Murai IH, Fernandes AL, Sales LP, Pinto AJ, Goessler KF, Duran CSC, Silva CBR, Franco AS, Macedo MB, Dalmolin HHH, Baggio J, Balbi GGM, Reis BZ, Antonangelo L, Caparbo VF, Gualano B, Pereira RMR. Effect of a single high dose of vitamin D3 on hospital length of stay in patients with moderate to severe COVID-19: a randomized clinical trial. JAMA. 2021;325:105360. https://doi.org/10.1001/jama.2020.26848.

95. Zimmermann P, Curtis N. Factors that influence the immune response to vaccination. Clin Microbiol Rev. 2019;32:e00084-e118. https://doi.org/10.1128/CMR.00084-18.

96. Nikolich-Zugich J, Knox KS, Rios CT, Natt B, Bhattacharya D, Fain MJ. SARS-CoV-2 and COVID-19 in older adults: what we may expect regarding pathogenesis, immune responses, and outcomes. Geroscience. 2020;42:505-14. https://doi.org/10. 1007/s11357-020-00186-0 (Epub 2020 Apr 10. Erratum in: Geroscience).

97. Rydyznski Moderbacher C, Ramirez SI, Dan JM, Grifoni A, Hastie KM, Weiskopf D, Belanger S, Abbott RK, Kim C, Choi J, Kato Y, Crotty EG, Kim C, Rawlings SA, Mateus J, Tse LPV, Frazier A, Baric R, Peters B, Greenbaum J, Ollmann Saphire E, Smith DM, Sette A, Crotty S. Antigen-specific adaptive immunity to SARS-CoV-2 in acute COVID-19 and associations with age and disease severity. Cell. 2020;183:996-1012.e19. https:// doi.org/10.1016/j.cell.2020.09.038 (Epub 2020 Sep 16).

98. Rondy M, El Omeiri N, Thompson MG, Levêque A, Moren A, Sullivan SG. Effectiveness of influenza vaccines in preventing severe influenza illness among adults: a systematic review and meta-analysis of test-negative design case-control studies. J Infect. 2017;75:381-94. https://doi.org/10.1016/j.jinf.2017.09. 010 (Epub 2017 Sep 18).

99. Nakaya HI, Hagan T, Duraisingham SS, Lee EK, Kwissa M, Rouphael N, Frasca D, Gersten M, Mehta AK, Gaujoux R, Li GM, Gupta S, Ahmed R, Mulligan MJ, Shen-Orr S, Blomberg BB, Subramaniam S, Pulendran B. Systems analysis of immunity to influenza vaccination across multiple years and in diverse populations reveals shared molecular signatures. Immunity. 2015;43:1186-98. https://doi.org/10.1016/j.immuni.2015.11. 012.

100. To KK, Hung IF, Ip JD, Chu AW, Chan WM, Tam AR, Fong $\mathrm{CH}$, Yuan S, Tsoi HW, Ng AC, Lee LL, Wan P, Tso E, To WK, Tsang D, Chan KH, Huang JD, Kok KH, Cheng VC, Yuen KY. COVID-19 re-infection by a phylogenetically distinct SARS-coronavirus-2 strain confirmed by whole genome sequencing. Clin Infect Dis. 2020. https://doi.org/10.1093/cid/ciaa1275 (Epub ahead of print).

101. Tillett RL, Sevinsky JR, Hartley PD, Kerwin H, Crawford N, Gorzalski A, Laverdure C, Verma SC, Rossetto CC, Jackson D, Farrell MJ, Van Hooser S, Pandori M. Genomic evidence for reinfection with SARS-CoV-2: a case study. Lancet Infect Dis. 2021;21:52-8. https://doi.org/10.1016/S1473-3099(20)30764-7 (Epub 2020 Oct 12).

102. Lei WT, Shih PC, Liu SJ, Lin CY, Yeh TL. Effect of probiotics and prebiotics on immune response to influenza vaccination in adults: a systematic review and meta-analysis of randomized controlled trials. Nutrients. 2017;9:1175. https://doi.org/10.3390/ nu9111175.

103. Zimmermann $\mathrm{P}$, Curtis N. The influence of probiotics on vaccine responses-a systematic review. Vaccine. 2018;36:207-13. https://doi.org/10.1016/j.vaccine.2017.08.069 (Epub 2017 Sep 18).

104. Mudgal R, Nehul S, Tomar S. Prospects for mucosal vaccine: shutting the door on SARS-CoV-2. Hum Vaccin Immunother. 2020;16:2921-31. https://doi.org/10.1080/21645515.2020.18059 92 (Epub 2020 Sep 15).

105. Gou W, Fu Y, Yue L, Chen GD, Cai X, Shuai M, Xu F, Yi X, Chen H, Zhu Y, Xiao ML, Jiang Z, Miao Z, Xiao C, Shen B, Wu X, Zhao H, Ling W, Wang J, Chen YM, Guo T, Zheng JS. Gut microbiota, inflammation, and molecular signatures of host response to infection. J Genet Genom. 2021;S16738527(21):00094-101. https://doi.org/10.1016/j.jgg.2021.04.002.

Publisher's Note Springer Nature remains neutral with regard to jurisdictional claims in published maps and institutional affiliations. 